\title{
Knowledge of Zika Virus Disease Prevention Methods, among Female Caregivers That Bring Babies for Immunization in a Teaching Hospital, Southeast Nigeria
}

\author{
Edmund 0. Ndibuagu1,2,3*, Peter E. Chime ${ }^{2,4}$, Sylvester O. Nweze ${ }^{2,3,5}$ \\ ${ }^{1}$ Department of Community Medicine and Primary Health Care, Enugu State University College of Medicine, \\ Enugu, Nigeria \\ ${ }^{2}$ Enugu State University Teaching Hospital, Enugu, Nigeria \\ ${ }^{3}$ Esucom Health Care Delivery Research Initiative, Enugu State University College of Medicine, Enugu, Nigeria \\ ${ }^{4}$ Department of Medicine, Enugu State University College of Medicine, Enugu, Nigeria \\ ${ }^{5}$ Department of Obstetrics \& Gynaecology, Enugu State University College of Medicine, Enugu, Nigeria \\ Email: *edmund.ndibuagu@esut.edu.ng
}

How to cite this paper: Ndibuagu, E.O., Chime, P.E. and Nweze, S.O. (2021) Knowledge of Zika Virus Disease Prevention Methods, among Female Caregivers That Bring Babies for Immunization in a Teaching Hospital, Southeast Nigeria. Health, 13, 1410-1430.

https://doi.org/10.4236/health.2021.1311101

Received: September 26, 2021

Accepted: November 27, 2021

Published: November 30, 2021

Copyright $\odot 2021$ by author(s) and Scientific Research Publishing Inc. This work is licensed under the Creative Commons Attribution International License (CC BY 4.0).

http://creativecommons.org/licenses/by/4.0/

\begin{abstract}
Zika virus disease is a disease of public health importance and was declared a "Public Health Emergency of International Concern", by the World Health Organization on February 1, 2016. It is mostly transmitted through the bite of Aedes aegypti and Aedes albopictus mosquitos. Transmission can also occur through blood transfusion and sexual intercourse. It could cause microcephaly and other neurological problems in newborns and adults, such as Guillain-Barre syndrome. It could also lead to abortion and stillbirth in pregnant women. Prevention methods are essentially targeted at transmission routes, which are mosquito bite, sexual intercourse, and blood transfusion. The study was of observational, descriptive, cross-sectional design, and conducted in a tertiary health institution in the Southeast geopolitical zone of Nigeria. Two hundred and fifty-six female caregivers participated in the study, with most of them being within the childbearing age group, and educated up to tertiary level. The objective was to assess the knowledge of Zika virus infection prevention methods, among female caregivers that bring babies for immunization in a Teaching Hospital, Southeast Nigeria. Out of the eight questions that sought to assess the knowledge level of the respondents, they scored $50 \%$ and above only in three, which were on prevention through protection against mosquito bite $(60.5 \%)$, avoiding unnecessary blood transfusion in endemic areas (53.9\%), and avoidance of oily meals not being a preventive measure (51.2\%). Respondents in the childbearing age group, and those with higher
\end{abstract}


educational qualifications, generally exhibited higher knowledge level than the other respondents. Scores on questions that sought to assess their knowledge on prevention aspects related to sexual behavior, and vaccination were poor. Sensitization, or awareness creation activities for persons in this study area, ought to be designed to address the observed gaps.

\section{Keywords}

Knowledge, Zika Virus, Prevention, Methods

\section{Introduction}

Zika virus infection has become a disease of global public health importance with its sporadic outbreaks from one region to another [1]. It was first isolated from a febrile Rhesus monkey in the Zika forest of Uganda in 1947, and named after the forest in 1952 [2]. Human infection was first documented in Uganda and the United Republic of Tanzania in 1952 [3]. Since Zika virus infection report in Uganda, there has been documented evidence of its spread to other Asian and African countries like Senegal [4], Ivory Coast, Egypt, India, Malaysia, Philippine [5], Indonesia [6] [7], Colombia, and Brazil [8]. Mosquito-transmitted Zika virus infection has been reported in 86 countries and territories around the world on 20 July, 2018 [3]. The outbreaks in 2015 and 2016 were a major challenge due to drift from its earlier known benign exanthematous spectrum to causing microcephaly in newborn [9].

Two genetically distinct isolates have been well characterized; the Asian and African strains [2] [5]. Its spread follows a bite of day-time-active Aedes specie of mosquitoes; the Aedes aegypti and Aedes albopictus, but commoner with Aedes aegypti [10]. Aedes aegypti mosquito also transmits Yellow fever, Dengue fever and Chikungunya disease [3]. Transmission of Zika virus can also occur through blood transfusion and sexual intercourse, as noted in Argentina, France, Chile, Italy, and New Zealand [11] [12]. Sexual transmission of Zika virus was initially known to be through heterosexual vaginal route, but on February $2^{\text {nd }}$, 2016, the United States of America Center for Disease Control and Prevention (CDC) informed the world of the first case of transmission of Zika virus sexually through the anal route in a man [13]. There is also suspicion of transmission through oral sex [11]. Transmission through organ transplantation has also been documented [3]. Furthermore, Zika virus infection can equally spread by vertical transmission via mother-to-child transmission during pregnancy [11] [14] [15]. This intra-uterine infection has recently been linked to microcephaly. In addition to microcephaly in the newborn, Zika virus infection in the pregnant mother also causes other congenital malformations in the newborn, collectively known as congenital Zika syndrome. This could manifest as eye abnormalities, limb contractures, hearing loss, and high muscle tone. The infection can also lead to preterm delivery and stillbirth [3]. Infection in the adult may result in neurolog- 
ical complications such as Guillain-Barre syndrome [16]. Up to eighty percent of infections are asymptomatic, but when symptoms occur, it presents with nonspecific features like headache, mild fever, arthralgia, conjunctivitis, myalgia, and cutaneous maculopapular rash [3].

Treatment of Zika virus infection is basically symptomatic and supportive treatment as there is no proven cure at present. The mainstay in the management of Zika virus infection lies basically in its prevention. Prevention methods are essentially targeted at transmission routes, which are mosquito bite, sexual intercourse, and blood transfusion. Organ transplant as a route of transmission is still rare, and more research work is presumably being done on it [3]. Mosquito bite protection can be achieved via the use of mosquito repellent, wearing long-sleeved shirts and long trousers, use of mosquito nets, sleeping or resting in screened or air-conditioned rooms and environmental cleanliness. Prevention of transmission through the sexual route can be done through practice of safer sex by pregnant women, which could involve use of barrier contraception such as condom, abstinence of sexual activity throughout the duration of pregnancy, and abstinence from sexual activity for at least two months for women and six months for men who are returning from areas of active Zika virus transmission [3]. The United States of America Centers for Disease Control and Prevention has recommended preventing Zika virus infection through blood in areas where there is an outbreak by screening potential blood donors [17].

The then "explosive spread with devastating neurological sequel" in the Americas, and the Caribbean, especially Brazil made the World Health Organization (WHO) to declare Zika virus disease a "Public Health Emergency of International Concern" on 1st February, 2016 [16]. The Zika virus strain in Brazil then was strongly linked to neurologic complications of congenital microcephaly, and Guillain-Barré Syndrome [18]. With increased global travels for economic, medical and social tourisms, no country of the world is spared from this virus [9]. In 1954, the first three cases of Zika virus infection in Nigeria, though detected in 1952, were reported in Oyo state [19]. With last United Nation's July 1, 2021 population estimate of two hundred and eleven million, four hundred thousand, seven hundred and eight persons $(211,400,708)$; Nigeria has the highest population in Africa [20], and thus has a high risk of Zika virus infection, also due to endemicity of mosquito-borne infections such as malaria and yellow fever.

With the unavailability of vaccines and antiviral drugs for treatment of Zika virus disease, coupled with the global outbreaks and consequent neurologic morbidity associated with the infection, there is a great need for knowledge of its prevention methods. Therefore, this study is designed to assess the knowledge of Zika virus disease prevention methods, among female caregivers that bring babies for immunization in a Teaching hospital, Southeast Nigeria. Majority of these caregivers are of childbearing age, and hence would bear a significant brunt of Zika virus infection, in the situation of any outbreak. 


\section{Materials and Methods}

Nigeria has the highest population in Africa and is divided into thirty-six states and one federal capital territory, which like the states; is an administrative unit. The states are further grouped into six geo-political zones, which are however not administrative units. Enugu state is one of the states in the Southeast geo-political zone and is made up of seventeen Local Government Areas (LGAs). These LGAs are administrative units and are made up of five urban, and twelve rural LGAs. The state is one of the five states that are predominantly inhabited by people of the Igbo tribe. There are however few people from the other ethnic groups, living in Enugu state [21]. This study was conducted in a State-owned tertiary health facility (Enugu State University Teaching Hospital), located in Enugu north, one of the three urban LGAs in the state capital territory. Residents of Enugu capital territory are mostly civil servants and traders.

The study was of observational, descriptive, cross-sectional design. It was conducted among female caregivers who brought babies for immunization at the Immunization unit of the hospital. Female caregivers who were staff of the hospital were excluded from the study since Zika virus disease sensitization talk was recently given to health workers in the study health facility about two weeks prior to the conduct of the study.

It is estimated that the minimum weekly immunization coverage in the hospital was about two hundred and sixty-three (263) babies. Using a formula for sample size estimation [22], sample size for one week was estimated to be one hundred and fifty-six (156). Though the data collection was initially planned to be completed within one week, logistics issues hampered this, hence the sample collection was stretched to nine weeks. It was conducted between November 2016, and February 2017. A junior resident in the department of Community Medicine was trained as a research assistant. He used Interviewer administered questionnaire to collect information from ten randomly selected caregivers on each day of immunization. Mondays, Wednesdays, and Fridays were the usual immunization days in the hospital. An average of 88 female Caregivers brought babies for immunization on each of the three stated immunization days. During the usual health talk, just before the commencement of the immunization proper, a basket with folded pieces of paper was passed around, and the caregivers requested to pick one. The word "YES" was written on ten of those pieces of paper, while the rest had "NO" written on them. Those that picked "YES" were recruited into the study, after giving informed consent. Anyone that declined consent was replaced through repeat balloting. This meant that thirty (30) respondents were interviewed each week for eight weeks, while sixteen respondents were interviewed on the ninth week, making a total of two hundred and fifty-six (256). Extra one hundred (100) respondents were added to the calculated one hundred and fifty-six (156), to enhance the validity of the responses obtained. Statistical Package for Social Sciences (SPSS) version 20.0 was used in analyzing the information obtained from respondents. The data generated were expressed 
in percentages of those with the correct knowledge on the ZVD preventive methods, percentages of those that did not have the knowledge, and percentages of those that were uncertain of what were ZVD preventive methods. These were presented in terms of the age and educational level of the respondents. Those with percentage scores that were $50.0 \%$ and above were considered to have good knowledge of the Zika virus disease preventive methods, while those with scores less than $50 \%$ were considered to have poor knowledge.

The Ethical Review Committee of Enugu State University Teaching Hospital gave Ethical clearance for this study. Before administering the questionnaire, the interviewer explained the study objectives to each respondent and secured informed consent. Though the study could be said to have given the correct picture of knowledge on ZVD prevention methods among female caregivers that bring babies for immunization at Enugu State University Teaching hospital; drawing conclusions on percentage distribution of the knowledge among respondents in different age and educational level groups could be deceptive. This is because only very few (2.3\%) were 50 years and above. All the caregivers that brought babies for immunization were however included in the study since everybody needs to be knowledgeable about ZVD prevention methods. Also, persons who reside in urban areas as seen in this study population are usually more knowledgeable than those in the rural areas, since they are generally more educated, and have better access to information. These are limitations to using findings in this study to represent the knowledge of Zika virus prevention methods among female caregivers in Enugu state, Southeast Nigeria. However, we limited our discussions on age and educational level patterns of the results, to respondents in childbearing age group.

\section{Results}

\section{The number of respondents in this study was 256 female caregivers}

Socio-Demographic Characteristics: Most of the respondents were between the ages of 20 to 49 years (94.2\%), predominantly Igbos by tribe (92.2\%), married (89.5\%), and practiced Christian religion (94.9\%). About half of the respondents had tertiary level of education (50.4\%), followed by $25.4 \%$ with secondary level education, and $21.1 \%$ with postgraduate level education. Almost half were Civil servants (48.4\%), followed by Petty traders (15.2\%) (Table 1)

Knowledge of Zika virus disease prevention methods among different age groups: About half of the respondents had correct knowledge that Zika virus infection cannot be prevented by staying away from sunlight (49.6\%). Many of them were however not sure whether staying away from sunlight can prevent Zika virus transmission (45.3\%), while $5.1 \%$ of them gave the incorrect response. Respondents aged 20 - 29 years recorded the highest correct knowledge score (55.6\%). Among respondents in the childbearing age group, 40 - 49 age group and 30 - 39 years age groups had close scores of $47.6 \%$ and $46.4 \%$ respectively. The highest score that Zika virus infection can be prevented by protecting one's 
Table 1. Socio-demographic characteristics of respondents.

\begin{tabular}{|c|c|c|}
\hline \multirow{2}{*}{ Variable } & $\mathbf{N}$ & $\%$ \\
\hline & $(256)$ & $(100)$ \\
\hline \multicolumn{3}{|l|}{ Age Range (yrs) } \\
\hline Below 19 & 9 & 3.5 \\
\hline $20-29$ & 108 & 42.2 \\
\hline $30-39$ & 112 & 43.8 \\
\hline $40-49$ & 21 & 8.2 \\
\hline $50-59$ & 3 & 1.2 \\
\hline $60-69$ & 2 & 0.8 \\
\hline 70 and above & 1 & 0.4 \\
\hline \multicolumn{3}{|l|}{ Tribe } \\
\hline Igbo & 236 & 92.2 \\
\hline Efik & 1 & 0.4 \\
\hline Yoruba & 6 & 2.3 \\
\hline Hausa & 8 & 3.1 \\
\hline Igala & 1 & 0.4 \\
\hline Cross Rivers & 1 & 0.4 \\
\hline Benue & 2 & 0.8 \\
\hline West Country & 1 & 0.4 \\
\hline \multicolumn{3}{|l|}{ Marital Status } \\
\hline Single & 229 & 89.5 \\
\hline Married & 26 & 10.2 \\
\hline Divorced/Separated & 1 & 0.4 \\
\hline \multicolumn{3}{|l|}{ Religion } \\
\hline Christian & 243 & 94.9 \\
\hline Muslim & 8 & 3.1 \\
\hline Traditional Religion & 5 & 2.0 \\
\hline \multicolumn{3}{|l|}{ Educational Level } \\
\hline No Formal Education & 3 & 1.2 \\
\hline Primary Level & 5 & 2.0 \\
\hline Secondary Level & 65 & 25.4 \\
\hline Tertiary Level & 129 & 50.4 \\
\hline Postgraduate Level & 54 & 21.1 \\
\hline
\end{tabular}




\section{Continued}

\begin{tabular}{ccc}
\hline Occupation & 5 & \\
Nothing & 6 & 2.0 \\
Farmer & 21 & 2.3 \\
Teacher & 39 & 8.2 \\
Petty Trader & 124 & 15.2 \\
Civil Servant & 7 & 48.4 \\
Public Servant & 29 & 2.7 \\
Student & 2 & 11.3 \\
NYSC & 7 & 0.8 \\
Business & 1 & 2.7 \\
Hair Dressing & 2 & 0.4 \\
Engineer & 3 & 0.8 \\
Tailoring/Fashion Designer & 1 & 1.2 \\
Banking & 1 & 0.4 \\
Optometrist & 1 & 0.4 \\
Private Organisation & 3.7 \\
Nursing & 1 & 0.4 \\
\hline
\end{tabular}

self from mosquito bite was recorded by persons aged 20 - 29 years (67.6\%), followed by those aged 30 - 39 years (58.9\%), and then $40-49$ years $(47.6 \%)$. The total correct knowledge score on Zika virus infection is prevented by protecting oneself from mosquito bites was $60.5 \%$. Very few gave the incorrect response (4.7\%), while $34.8 \%$ were not sure. On the use of condom during sexual intercourse, to prevent infection by pregnant women in Zika virus endemic area; 20 29 years age group had the highest knowledge $(42.8 \%)$, followed by 30 - 39 years age group (38.4\%), and then 40 - 49 years age group (23.8\%). Percentage total of $37.9 \%$ of respondents had the correct knowledge, $14.1 \%$ did not have the knowledge, while $48.0 \%$ were not sure. The percentage score of respondents aged 20 29 years (39.8\%) was slightly higher than the score for those aged 30 - 39 years (39.3\%); on the question of Zika virus infection being prevented by pregnant women abstaining from sexual intercourse in Zika virus endemic areas. Those aged 40 - 49 years also had a close percentage score of $33.3 \%$. The total percentage correct knowledge score on this abstinence from sexual intercourse by pregnant women was $38.3 \%$, the incorrect response was $16.0 \%$, while $45.7 \%$ of the respondents were not sure. Respondents aged 40 - 49 years recorded the highest percentage score (47.6\%) on the knowledge that abstinence from sexual intercourse for six months by men returning from Zika virus endemic areas, is a method of preventing Zika virus infection. Respondents aged $20-29$ years and 30 - 39 years had correct knowledge score of $38.9 \%$ and $31.3 \%$ respectively. The 
total correct knowledge score for men abstaining from sexual intercourse for six months was $35.2 \%$, while $13.3 \%$ recorded incorrect response. As high as $51.6 \%$ of the total respondents were not sure if men abstaining for six months was a recommended method of preventing Zika virus infection. Respondents aged 20 29 years, 30 - 39 years, and 40 - 49 years had close percentage knowledge scores (56.5\%, 53.6\%, and $57.1 \%$ respectively), on preventing Zika virus infection by avoiding unnecessary blood transfusion in Zika virus endemic areas. Slightly more than half of the respondents (53.9\%) had this knowledge, while only $4.7 \%$ recorded incorrect response, but as high as $41.4 \%$ were not sure if the avoidance of unnecessary blood transfusion endemic areas could prevent Zika virus transmission. Most of the respondents aged 20 - 29 years (59.3\%) knew that avoiding eating too many oily meals is not Zika virus infection preventive method. A little less than half (48.2\%) of those aged 30 - 39 years also had this knowledge, while $42.9 \%$ of those aged $40-49$ years knew that avoiding eating too many oily meals does not prevent Zika virus infection. In all, $51.2 \%$ of respondents knew that avoiding eating too many oily meals does not prevent Zika virus infection, while only $5.1 \%$ gave the incorrect response, and $43.8 \%$ were not sure of the correct response. An almost equal percentage of those aged 20 - 29 years (41.7\%), and those aged 30 - 39 years $(41.1 \%)$ knew that there is no vaccine for preventing Zika virus infection. Only $19.0 \%$ of respondents aged $40-49$ years knew that Zika virus infection does not have a vaccine. Overall, only $37.5 \%$ of respondents knew that there is no vaccine for preventing Zika virus infection, while $13.3 \%$ believed that Zika virus infection has a vaccine. Almost half of the respondents were not sure of the correct response (Table 2).

Knowledge of Zika virus disease prevention methods among different educational level groups: More than half of respondents with tertiary (51.9\%) and postgraduate (53.7\%) educational levels knew that staying away from excessive sunlight does not prevent Zika virus infection. Only one respondent with primary level education (20\%), and $44.6 \%$ of those with secondary education had this knowledge. A total of $49.6 \%$ of respondents had the knowledge, while only $5.1 \%$ gave incorrect response. $45.3 \%$ of respondents were not sure of the correct response. Correct response that Zika virus infection can be prevented by protecting one's self from mosquito bite, was given by $70.4 \%$ of respondents with postgraduate education, $68.2 \%$ of those with tertiary education, $43.1 \%$ of those with secondary education, and no respondent with primary education, out of the 5 with primary education. Out of the three persons with no formal education, only one person had the correct response. Overall, $60.5 \%$ of respondents knew that protection against mosquito bite is a method of preventing Zika virus infection, and only $4.7 \%$ gave incorrect response. However, $34.8 \%$ of all respondents were not sure of the correct response. Knowledge that Zika virus infection can be prevented by pregnant women using condom for sexual intercourse in Zika endemic areas were recorded as follows; postgraduate level had $40.7 \%$, tertiary level had $45.0 \%$, secondary level had $24.6 \%$, and primary level had $0.0 \%$. Only one person out of the three that participated among those that all the 
Table 2. Knowledge of Zika virus disease prevention methods among different age groups.

\begin{tabular}{|c|c|c|c|c|}
\hline Question & $\begin{array}{c}\text { Age Range } \\
\text { (years) }\end{array}$ & $\begin{array}{l}\text { Correct } \\
\text { Response }\end{array}$ & $\begin{array}{l}\text { Incorrect } \\
\text { Response }\end{array}$ & $\begin{array}{l}\text { Not } \\
\text { Sure }\end{array}$ \\
\hline \multirow{8}{*}{$\begin{array}{l}\text { Zika virus infection } \\
\text { can be prevented by } \\
\text { staying away from } \\
\text { excessive sunlight }\end{array}$} & 19 and less & $3(33.3 \%)$ & $0(0.0 \%)$ & $6(66.7 \%)$ \\
\hline & $20-29$ & $60(55.6 \%)$ & $3(2.8 \%)$ & $45(41.7 \%)$ \\
\hline & $30-39$ & $52(46.4 \%)$ & $9(8.0 \%)$ & $51(45.5 \%)$ \\
\hline & $40-49$ & $10(47.6 \%)$ & $0(0.0 \%)$ & $11(52.4 \%)$ \\
\hline & $50-59$ & $1(33.3 \%)$ & $0(0.0 \%)$ & $2(66.7 \%)$ \\
\hline & $60-69$ & $1(50.0 \%)$ & $0(0.0 \%)$ & $1(50.0 \%)$ \\
\hline & 70 and above & $0(0.0 \%)$ & $1(100.0 \%)$ & $0(0.0 \%)$ \\
\hline & Total & $127(49.6 \%)$ & $13(5.1 \%)$ & $116(45.3 \%)$ \\
\hline \multirow{8}{*}{$\begin{array}{l}\text { Zika virus infection } \\
\text { can be prevented } \\
\text { by protecting one's } \\
\text { self from mosquito bite }\end{array}$} & 19 and less & $5(55.6 \%)$ & $2(22.2 \%)$ & $2(22.2 \%)$ \\
\hline & $20-29$ & $73(67.6 \%)$ & $6(5.6 \%)$ & $29(26.9 \%)$ \\
\hline & $30-39$ & $66(58.9 \%)$ & $2(1.8 \%)$ & $44(39.3 \%)$ \\
\hline & $40-49$ & $10(47.6 \%)$ & $1(4.8 \%)$ & $10(47.6 \%)$ \\
\hline & $50-59$ & $1(33.3 \%)$ & $0(0.0 \%)$ & $2(66.7 \%)$ \\
\hline & $60-69$ & $0(0.0 \%)$ & $0(0.0 \%)$ & $2(100.0 \%)$ \\
\hline & 70 and above & $0(0.0 \%)$ & $1(100.0 \%)$ & $0(0.0 \%)$ \\
\hline & Total & $155(60.5 \%)$ & $12(4.7 \%)$ & $89(34.8 \%)$ \\
\hline \multirow{8}{*}{$\begin{array}{l}\text { Zika virus infection } \\
\text { can be prevented by } \\
\text { pregnant women using } \\
\text { condom for sexual } \\
\text { intercourse in Zika } \\
\text { virus endemic areas }\end{array}$} & 19 and less & $2(22.2 \%)$ & $2(22.2 \%)$ & $5(55.6 \%)$ \\
\hline & $20-29$ & $46(42.8 \%)$ & $17(15.7 \%)$ & $45(41.7 \%)$ \\
\hline & $30-39$ & $43(38.4 \%)$ & $11(9.8 \%)$ & $58(51.8 \%)$ \\
\hline & $40-49$ & $5(23.8 \%)$ & $5(23.8 \%)$ & $11(52.4 \%)$ \\
\hline & $50-59$ & $0(0.0 \%)$ & $1(33.3 \%)$ & $2(66.7 \%)$ \\
\hline & $60-69$ & $0(0.0 \%)$ & $0(0.0 \%)$ & $2(100.0 \%)$ \\
\hline & 70 and above & $1(100.0 \%)$ & $0(0.0 \%)$ & $0(0.0 \%)$ \\
\hline & Total & 97 (37.9\%) & $36(14.1 \%)$ & $123(48.0 \%)$ \\
\hline \multirow{8}{*}{$\begin{array}{l}\text { Zika virus infection } \\
\text { can be prevented by } \\
\text { pregnant women } \\
\text { abstaining from sex } \\
\text { in Zika virus } \\
\text { endemic areas }\end{array}$} & 19 and less & $3(33.3 \%)$ & $3(33.3 \%)$ & $3(33.3 \%)$ \\
\hline & $20-29$ & $43(39.8 \%)$ & $16(14.8 \%)$ & $49(45.4 \%)$ \\
\hline & $30-39$ & $44(39.3 \%)$ & $13(11.6 \%)$ & $55(49.1 \%)$ \\
\hline & $40-49$ & $7(33.3 \%)$ & $8(38.1 \%)$ & $6(28.6 \%)$ \\
\hline & $50-59$ & $0(0.0 \%)$ & $1(33.3 \%)$ & $2(66.7 \%)$ \\
\hline & $60-69$ & $1(50.0 \%)$ & $0(0.0 \%)$ & $1(50.0 \%)$ \\
\hline & 70 and above & $0(0.0 \%)$ & $0(0.0 \%)$ & $1(100.0 \%)$ \\
\hline & Total & $98(38.3 \%)$ & $41(16.0 \%)$ & $117(45.7 \%)$ \\
\hline
\end{tabular}




\section{Continued}

\begin{tabular}{|c|c|c|c|c|}
\hline \multirow{8}{*}{$\begin{array}{l}\text { Zika virus infection } \\
\text { can be prevented by } \\
\text { men returning from } \\
\text { endemic areas } \\
\text { abstaining from sex } \\
\text { for about six (6) months }\end{array}$} & 19 and less & $3(33.3 \%)$ & $3(33.3 \%)$ & $3(33.3 \%)$ \\
\hline & $20-29$ & $42(38.9 \%)$ & $15(13.9 \%)$ & $51(47.2 \%)$ \\
\hline & $30-39$ & $35(31.3 \%)$ & $14(12.5 \%)$ & $63(56.3 \%)$ \\
\hline & $40-49$ & $10(47.6 \%)$ & $1(4.8 \%)$ & $10(47.6 \%)$ \\
\hline & $50-59$ & $0(0.0 \%)$ & $1(33.3 \%)$ & $2(66.7 \%)$ \\
\hline & $60-69$ & $0(0.0 \%)$ & $0(0.0 \%)$ & $2(100.0 \%)$ \\
\hline & 70 and above & $0(0.0 \%)$ & $0(0.0 \%)$ & $1(100.0 \%)$ \\
\hline & Total & $90(35.2 \%)$ & $34(13.3 \%)$ & $132(51.6 \%)$ \\
\hline \multirow{8}{*}{$\begin{array}{l}\text { Zika virus infection } \\
\text { can be prevented } \\
\text { by avoiding } \\
\text { unnecessary blood } \\
\text { transfusion in } \\
\text { endemic areas }\end{array}$} & 19 and less & $3(33.3 \%)$ & $1(11.1 \%)$ & $5(55.6 \%)$ \\
\hline & $20-29$ & $61(56.5 \%)$ & $4(3.7 \%)$ & $43(39.8 \%)$ \\
\hline & $30-39$ & $60(53.6 \%)$ & $4(3.6 \%)$ & $48(42.9 \%)$ \\
\hline & $40-49$ & $12(57.1 \%)$ & $2(9.5 \%)$ & $7(33.3 \%)$ \\
\hline & $50-59$ & $1(33.3 \%)$ & $0(0.0 \%)$ & $2(66.7 \%)$ \\
\hline & $60-69$ & $1(50.0 \%)$ & $0(0.0 \%)$ & $1(50.0 \%)$ \\
\hline & 70 and above & $0(0.0 \%)$ & $0(0.0 \%)$ & $1(100.0 \%)$ \\
\hline & Total & $138(53.9 \%)$ & $12(4.7 \%)$ & $106(41.4 \%)$ \\
\hline \multirow{8}{*}{$\begin{array}{l}\text { Zika virus infection } \\
\text { can be prevented by } \\
\text { avoiding eating too } \\
\text { much oily meals }\end{array}$} & 19 and less & $3(33.3 \%)$ & $1(11.1 \%)$ & $5(55.6 \%)$ \\
\hline & $20-29$ & $64(59.3 \%)$ & $4(3.7 \%)$ & $40(37.0 \%)$ \\
\hline & $30-39$ & $54(48.2 \%)$ & $4(3.6 \%)$ & $54(48.2 \%)$ \\
\hline & $40-49$ & $9(42.9 \%)$ & $3(14.3 \%)$ & $9(42.9 \%)$ \\
\hline & $50-59$ & $1(33.3 \%)$ & $0(0.0 \%)$ & $2(66.7 \%)$ \\
\hline & $60-69$ & $0(0.0 \%)$ & $1(50.0 \%)$ & $1(50.0 \%)$ \\
\hline & 70 and above & $0(0.0 \%)$ & $0(0.0 \%)$ & $1(100.0 \%)$ \\
\hline & Total & $131(51.2 \%)$ & $13(5.1 \%)$ & $112(43.8 \%)$ \\
\hline \multirow{8}{*}{$\begin{array}{l}\text { There is vaccine for } \\
\text { the prevention of } \\
\text { Zika virus infection }\end{array}$} & 19 and less & $1(11.1 \%)$ & $3(33.3 \%)$ & $5(55.6 \%)$ \\
\hline & $20-29$ & 45 (41.7\%) & $14(13.0 \%)$ & 49 (45.4\%) \\
\hline & $30-39$ & $46(41.1 \%)$ & $16(14.3 \%)$ & $50(44.6 \%)$ \\
\hline & $40-49$ & $4(19.0 \%)$ & $1(4.8 \%)$ & $16(76.2 \%)$ \\
\hline & $50-59$ & $0(0.0 \%)$ & $0(0.0 \%)$ & $3(100.0 \%)$ \\
\hline & $60-69$ & $0(0.0 \%)$ & $0(0.0 \%)$ & $2(100.0 \%)$ \\
\hline & 70 and above & $0(0.0 \%)$ & $0(0.0 \%)$ & $1(100.0 \%)$ \\
\hline & Total & $96(37.5 \%)$ & $34(13.3 \%)$ & $126(49.2 \%)$ \\
\hline
\end{tabular}

had no formal education had correct knowledge. A total of $37.9 \%$ of respondents had the correct response on this use of condoms by pregnant women in Zika virus disease endemic areas, while $14.1 \%$ gave incorrect response. Almost half of 
respondents $(48.0 \%)$ were not sure of the correct response. Correct response on abstinence from sexual intercourse by pregnant women as a means of preventing Zika virus disease was given as follows; postgraduate level recorded $35.2 \%$, tertiary level had $45.0 \%$, secondary level had $32.3 \%$, while primary level and those without formal education had $0.0 \%$ each. Overall, $38.3 \%$ respondents gave the correct response, while $16.0 \%$ gave the incorrect response. Close to half of all the respondents (45.7\%) were not sure of the response to give. Six months abstinence from sexual intercourse as a Zika virus infection prevention method by men returning from Zika endemic areas was known by $29.6 \%$ of respondents with postgraduate education, $45.7 \%$ of those with tertiary education, $23.1 \%$ of those with secondary education, and $0.0 \%$ of those with primary, and no formal education each. Total of $35.2 \%$ respondents knew about the male abstinence for about six months as a preventive measure, while $13.3 \%$ of the respondents recorded incorrect response. About half of the respondents (51.6\%) were not sure of the response to give. On the avoidance of unnecessary blood transfusion in Zika virus disease endemic areas as a means of preventing infection; $63.0 \%$ of postgraduate level respondents gave the correct response, so did $58.9 \%$ of those with tertiary education, $41.5 \%$ of those with secondary education, and $20.0 \%$ of those with primary education. None of the respondents with no formal education had the knowledge. Overall, about half of the respondents gave the correct response, while only $4.7 \%$ gave the incorrect response. Many (41.4\%) were not sure of what response to give. Clearly more than half of the respondents with postgraduate education (63.0\%) knew that avoiding eating too much oily meals does not prevent one from getting Zika virus infection, while $55.8 \%$ of those with tertiary education gave the correct response about this, as well as $38.5 \%$ of those with secondary education. No participant with primary or no formal education responded correctly. About a half of all the respondents (51.2\%) gave the correct response about this, while only $5.1 \%$ gave the incorrect response. As high as $43.8 \%$ of the respondents, were not sure of the response to give. The knowledge that there is no Zika virus disease vaccine was recorded as follow; those with postgraduate education had $33.3 \%$, tertiary education group had $43.4 \%$, secondary education $33.8 \%$, while none of those with primary or no formal education gave the correct response. A total of $37.5 \%$ of respondents knew that there were no vaccines for Zika virus disease, $13.3 \%$ of them believed that Zika virus had vaccine, while $49.2 \%$ were not sure of the response to give (Table 3 ).

\section{Discussion}

Zika virus is an emerging infectious disease with attendant complications. It is a disease that constant efforts should be made to ensure that it is prevented, since it is preventable. The disease though has been reported in some parts of Americas, South East Asia, and Caribbean; is endemic in parts of Africa [23]. Nigeria is potentially a population where Zika virus infection could breakout, since there is evidence that the virus is widely circulated in Nigeria [24] [25]. The World 
Table 3. Knowledge of Zika virus disease prevention methods among different educational level groups.

\begin{tabular}{|c|c|c|c|c|}
\hline Question & $\begin{array}{c}\text { Educational } \\
\text { level }\end{array}$ & $\begin{array}{c}\text { Correct } \\
\text { Response }\end{array}$ & $\begin{array}{l}\text { Incorrect } \\
\text { Response }\end{array}$ & $\begin{array}{l}\text { Not } \\
\text { Sure }\end{array}$ \\
\hline \multirow{6}{*}{$\begin{array}{l}\text { Zika virus infection } \\
\text { can be prevented by } \\
\text { staying away from } \\
\text { excessive sunlight }\end{array}$} & $\begin{array}{l}\text { No formal } \\
\text { education }\end{array}$ & $1(33.3 \%)$ & $1(33.3 \%)$ & $1(33.3 \%)$ \\
\hline & Primary & $1(20.0 \%)$ & $0(0.0 \%)$ & $4(80.0 \%)$ \\
\hline & Secondary & $29(44.6 \%)$ & $4(6.2 \%)$ & $32(49.2 \%)$ \\
\hline & Tertiary & 67 (51.9\%) & $2(1.6 \%)$ & $60(46.5 \%)$ \\
\hline & Postgraduate & $29(53.7 \%)$ & $6(11.1 \%)$ & $19(35.2 \%)$ \\
\hline & Total & $127(49.6 \%)$ & $13(5.1 \%)$ & $116(45.3 \%)$ \\
\hline \multirow{6}{*}{$\begin{array}{l}\text { Zika virus infection } \\
\text { can be prevented } \\
\text { by protecting } \\
\text { one’s self from } \\
\text { mosquito bite }\end{array}$} & $\begin{array}{l}\text { No formal } \\
\text { education }\end{array}$ & $1(33.3 \%)$ & $1(33.3 \%)$ & $1(33.3 \%)$ \\
\hline & Primary & $0(0.0 \%)$ & $0(0.0 \%)$ & $5(100.0 \%)$ \\
\hline & Secondary & $28(43.1 \%)$ & $4(6.2 \%)$ & $33(50.8 \%)$ \\
\hline & Tertiary & $88(68.2 \%)$ & $4(3.1 \%)$ & $37(28.7 \%)$ \\
\hline & Postgraduate & $38(70.4 \%)$ & $3(5.6 \%)$ & $13(24.1 \%)$ \\
\hline & Total & $155(60.5 \%)$ & $12(4.7 \%)$ & $89(34.8 \%)$ \\
\hline \multirow{6}{*}{$\begin{array}{l}\text { Zika virus infection } \\
\text { can be prevented by } \\
\text { pregnant women } \\
\text { using condom for } \\
\text { sexual intercourse } \\
\text { in Zika virus } \\
\text { endemic areas }\end{array}$} & $\begin{array}{l}\text { No formal } \\
\text { education }\end{array}$ & $1(33.3 \%)$ & $0(0.0 \%)$ & $2(66.7 \%)$ \\
\hline & Primary & $0(0.0 \%)$ & $0(0.0 \%)$ & $5(100.0 \%)$ \\
\hline & Secondary & $16(24.6 \%)$ & $13(20.0 \%)$ & $36(55.4 \%)$ \\
\hline & Tertiary & $58(45.0 \%)$ & $11(8.5 \%)$ & $60(46.5 \%)$ \\
\hline & Postgraduate & $22(40.7 \%)$ & $12(22.2 \%)$ & $20(37.0 \%)$ \\
\hline & Total & 97 (37.9\%) & $36(14.1 \%)$ & $123(48.0 \%)$ \\
\hline \multirow{6}{*}{$\begin{array}{l}\text { Zika virus infection } \\
\text { can be prevented by } \\
\text { pregnant women } \\
\text { abstaining from } \\
\text { sex in Zika virus } \\
\text { endemic areas }\end{array}$} & $\begin{array}{l}\text { No formal } \\
\text { education }\end{array}$ & $0(0.0 \%)$ & $0(0.0 \%)$ & $3(100.0 \%)$ \\
\hline & Primary & $0(0.0 \%)$ & $0(0.0 \%)$ & $5(100.0 \%)$ \\
\hline & Secondary & $21(32.3 \%)$ & $17(26.2 \%)$ & $27(41.5 \%)$ \\
\hline & Tertiary & $58(45.0 \%)$ & $13(10.1 \%)$ & $58(45.0 \%)$ \\
\hline & Postgraduate & $19(35.2 \%)$ & $11(20.4 \%)$ & $24(44.4 \%)$ \\
\hline & Total & $98(38.3 \%)$ & $41(16.0 \%)$ & 117 (45.7\%) \\
\hline \multirow{6}{*}{$\begin{array}{l}\text { Zika virus infection } \\
\text { can be prevented by } \\
\text { men returning from } \\
\text { endemic areas } \\
\text { abstaining from } \\
\text { sex for about } \\
\text { six (6) months }\end{array}$} & $\begin{array}{l}\text { No formal } \\
\text { education }\end{array}$ & $0(0.0 \%)$ & $0(0.0 \%)$ & $3(100.0 \%)$ \\
\hline & Primary & $0(0.0 \%)$ & $0(0.0 \%)$ & $5(100.0 \%)$ \\
\hline & Secondary & $15(23.1 \%)$ & $13(20.0 \%)$ & 37 (56.9\%) \\
\hline & Tertiary & 59 (45.7\%) & $12(9.3 \%)$ & $58(45.0 \%)$ \\
\hline & Postgraduate & $16(29.6 \%)$ & $9(16.7 \%)$ & $29(53.7 \%)$ \\
\hline & Total & $90(35.2 \%)$ & $34(13.3 \%)$ & $132(51.6 \%)$ \\
\hline
\end{tabular}




\section{Continued}

\begin{tabular}{|c|c|c|c|c|}
\hline \multirow{6}{*}{$\begin{array}{l}\text { Zika virus infection } \\
\text { can be prevented by } \\
\text { avoiding unnecessary } \\
\text { blood transfusion } \\
\text { in endemic areas }\end{array}$} & $\begin{array}{l}\text { No formal } \\
\text { education }\end{array}$ & $0(0.0 \%)$ & $0(0.0 \%)$ & $3(100.0 \%)$ \\
\hline & Primary & $1(20.0 \%)$ & $0(0.0 \%)$ & $4(80.0 \%)$ \\
\hline & Secondary & $27(41.5 \%)$ & $7(10.8 \%)$ & $31(47.7 \%)$ \\
\hline & Tertiary & 76 (58.9\%) & $3(2.3 \%)$ & $50(38.8 \%)$ \\
\hline & Postgraduate & $34(63.0 \%)$ & $2(3.7 \%)$ & $18(33.3 \%)$ \\
\hline & Total & $138(53.9 \%)$ & $12(4.7 \%)$ & $106(41.4 \%)$ \\
\hline \multirow{6}{*}{$\begin{array}{l}\text { Zika virus infection } \\
\text { can be prevented } \\
\text { by avoiding eating } \\
\text { too much oily meals }\end{array}$} & $\begin{array}{l}\text { No formal } \\
\text { education }\end{array}$ & $0(0.0 \%)$ & $0(0.0 \%)$ & $3(100.0 \%)$ \\
\hline & Primary & $0(0.0 \%)$ & $1(20.0 \%)$ & $4(80.0 \%)$ \\
\hline & Secondary & $25(38.5 \%)$ & $5(7.7 \%)$ & $35(53.8 \%)$ \\
\hline & Tertiary & $72(55.8 \%)$ & $2(1.6 \%)$ & $55(42.6 \%)$ \\
\hline & Postgraduate & $34(63.0 \%)$ & $5(9.3 \%)$ & $15(27.8 \%)$ \\
\hline & Total & $131(51.2 \%)$ & $13(5.1 \%)$ & $112(43.8 \%)$ \\
\hline \multirow{6}{*}{$\begin{array}{l}\text { There is vaccine for } \\
\text { the prevention of } \\
\text { Zika virus infection }\end{array}$} & $\begin{array}{l}\text { No formal } \\
\text { education }\end{array}$ & $0(0.0 \%)$ & $0(0.0 \%)$ & $3(100.0 \%)$ \\
\hline & Primary & $0(0.0 \%)$ & $0(0.0 \%)$ & $5(100.0 \%)$ \\
\hline & Secondary & $22(33.8 \%)$ & $8(12.3 \%)$ & $35(53.8 \%)$ \\
\hline & Tertiary & $56(43.4 \%)$ & $15(11.6 \%)$ & $58(45.0 \%)$ \\
\hline & Postgraduate & $18(33.3 \%)$ & $11(20.4 \%)$ & $25(46.3 \%)$ \\
\hline & Total & $96(37.5 \%)$ & $34(13.3 \%)$ & $126(49.2 \%)$ \\
\hline
\end{tabular}

Health Organization has highlighted the importance of providing information on the preventive methods of Zika virus disease so that people can be protected from the disease and the complications [16]. It has also been pointed out that the neurological complications of Zika virus infection, could pose a long-term public health challenge [26].

There are some common myths in some West African countries, especially in the rural areas about the causation of febrile illnesses such as malaria. Some believe that such illnesses could be caused by excessive sunlight [27] [28]. Overall poor knowledge finding in this study (49.6\%), that staying away from excessive sunlight does not prevent Zika virus infection is worrisome, especially since this study was conducted in urban areas where almost all the respondents had at least secondary level education. However, respondents aged 20 - 29 years recorded good knowledge on this (55.6\%) (Table 2). Those that had postgraduate and tertiary educational levels also had good knowledge on this $(53.7 \%$ and $51.9 \%$ respectively) (Table 3). Higher educational attainment probably exposed respondents to information that made them know that excessive sunlight as a causative factor for febrile illnesses is a myth. In addition to low educational at- 
tainment, most respondents not being sure, or believing that staying away from excessive sunlight could prevent Zika virus infection, might have been as a result of probably some older ones migrating from the rural community, and thus still retaining some of the myths that were mostly held by rural dwellers. The respondents, overall exhibited good knowledge on preventing Zika virus infection, through protection against mosquito bite (60.5\%). Those within the childbearing age recording higher percentage knowledge scores on this (Table 2), implies that implementing Zika virus prevention strategies, using mosquito bite protection approach, will achieve desired outcomes, such as reduction in the number of $\mathrm{Zi}$ ka infected babies in that community. This correlates well with the finding in a study conducted among the same respondents at the same time, where out of $65.6 \%$ with knowledge that Zika virus is transmitted through mosquito bite, those within the childbearing age demonstrated better knowledge [29]. Respondents with postgraduate educational qualification recorded the highest percentage knowledge score $(70.4 \%)$ on preventing Zika virus infection through protection against mosquito bite (Table 3 ). They were followed by those with tertiary education (68.2\%), and then those with secondary education (43.1\%). Also in another study among the same sample population, on formal education related pattern of awareness and basic knowledge on Zika virus disease; respondents with higher educational qualifications demonstrated better knowledge on mosquito being the vector for Zika virus [30]. Only 4.7\% overall, giving the incorrect response, and $34.8 \%$ not being sure of the response to give, point to the possibility of getting most of the women in this study population to be equipped with this approach to Zika virus infection prevention, and to practice same; if health education programme targeting this group is properly implemented. Qualitative study conducted in Peru among women of Childbearing age, at about the same time with this study; revealed that most of the participants in six Focused Group Discussions knew that Zika virus disease can be prevented by protecting one's self from mosquito bite [31]. Most studies that seek to investigate knowledge of respondents on the mosquito bite as the route of Zika virus disease transmission, commonly demonstrated good knowledge score, [30] [32] [33] and by implication, new that Zika virus infection can be prevented by protecting one's self against mosquito bite. However, respondents frequently demonstrated poor knowledge on some specific mosquito bite protection methods, such as seen in a Zika virus study conducted in Philippines in 2018 [33], where only $26.6 \%$ of respondents knew that one can protect self from mosquito bite by wearing covering cloths, and $43.5 \%$ knew that using mosquito net at night protects one from mosquito bite.

Respondents recorded poor knowledge, overall (37.9\%) on use of condom by pregnant women to prevent Zika virus infection in endemic areas. Many of them $(48.0 \%)$ are not sure of the correct response to give, while $14.1 \%$ gave wrong response. For respondents in the childbearing age group, the highest number of correct response came from persons aged 20 - 29 years $(42.8 \%)$, followed by 30 - 
39 years age group (38.4\%) (Table 2). Since most pregnancies occur among persons in this age bracket, intensifying Zika virus disease health education activities for persons in this group will make most of them know about the use of condom in preventing Zika virus infection. Persons with tertiary education recorded the highest positive response (45.0\%), followed by those with postgraduate education (40.7\%), and then secondary education (24.6\%) (Table 3). Higher education level appears to have contributed favourably in the respondents' knowledge on the use of condom in pregnancy to prevent Zika virus infection. The overall knowledge recorded in this study, on the use of condom during pregnancy to prevent Zika virus infection is better than the findings among a University community located in an endemic zone in Mexico, where only $27.63 \%$ of women gave correct response [34]; and only a meager $6.1 \%$ of secondary school teachers in another study conducted in Philippines three years ago [33]. The apparent better finding in our study, when compared to that in the endemic zone in Mexico, could have been as a result of most of the respondents in the Mexico study being young undergraduates, and males were also included. This implies that they did not receive the usual health education talk given to many pregnant women during Antenatal visits, as obtained in Nigeria. This also could have been part of the reasons of the very poor knowledge level recorded among secondary school teachers in Philippines, since those teachers though females, could not have been exposed to the health education talks given to pregnant women during Antenatal visits. Another study conducted in the same Philippines at about the same time with the one among secondary school teachers appears to have justified this thinking about Antenatal health talks contributing to better Zika virus disease knowledge [35]. The study revealed that $24.5 \%$ of the respondents knew that Zika virus is transmitted through sexual intercourse, as against the $6.1 \%$ recorded among the secondary school teachers. This implied that $24.5 \%$ of respondents in that study could know that using condom by pregnant women in endemic areas, could prevent Zika virus infection. Good knowledge on sexual intercourse as route of Zika virus transmission could imply good knowledge on use of condom during pregnancy, or abstinence from sex, as a method of preventing Zika virus infection during outbreak, or in endemic areas. In this vein, a study conducted in Northern Nigeria at the same period of conducting this study revealed very poor knowledge on the sexual route of Zika virus transmission (5\%) [36].

Though respondents in the Northern Nigeria study were women of childbearing age, they were drawn from the general outpatient department, as against respondents in this study that were female caregivers that probably recently were delivered of babies. This means that our respondents probably had recent health education talks given to pregnant women, hence better equipped with Zika virus disease knowledge. Some studies done in the United States of America revealed higher knowledge levels on transmission of Zika virus through the sexual route [32] [37]. About half (49.8\%) of United States pregnant immigrants from Zika 
virus outbreak areas knew that Zika virus can be transmitted through sexual intercourse, while as high as $59 \%$ of respondents in a survey conduct among residents of New York City in the United States of America knew that Zika virus can be transmitted through sexual intercourse. The better knowledge level recorded in the United States of America studies could be as a result of that country being a lot more developed, with better health systems than Nigeria.

Knowledge on Zika virus infection prevention through, pregnant women abstaining from sex in Zika virus endemic areas was found to be almost the same score $(38.3 \%)$, as that recorded on use of condom by pregnant women for prevention (37.9\%). The age and educational level patterns were essentially similar (Table 2 and Table 3). Only 35.2\% of respondents knew that Zika virus infection can be prevented by men returning from endemic areas abstaining from sex for about six months. All those that gave correct response belonged to the childbearing age group (Table 2), and also had a minimum of secondary level education (Table 3). This further suggests that formal education positively contributes to improved knowledge on Zika virus prevention methods. Respondents in the childbearing age group, demonstrating better knowledge on this is encouraging, since they are really the ones that are required to put this into practice. Most of the respondents are not sure of the correct response (51.6\%), while only $13.3 \%$ did not know that men returning from Zika endemic areas ought to abstain from sex for six months, since they possibly could be carrying the virus in their semen. Poor knowledge on men from endemic areas abstaining from sexual intercourse appears to also obtain in developed countries. Our finding of $35.2 \%$ is even slightly higher than the $35 \%$ found among residents in New York City of the United States of America [37]. A qualitative study conducted among women of childbearing age, also revealed very poor knowledge level, with respect to men from Zika virus endemic areas abstaining from sex for six months. Among three groups in six Focused Group Discussions that knew that Zika virus can be transmitted through the sexual route, only two women knew of the recommended six months period of abstinence for men returning from endemic areas [31]. It will be beneficial to always highlight this Zika virus prevention practice, during any health promotion activity targeted at Zika virus prevention.

More than half of the respondents (53.9\%) knew that Zika virus can be prevented by avoiding unnecessary blood transfusion in endemic areas. More of the correct response came from persons in the childbearing age group (Table 2). Persons with higher educational level also recorded better knowledge on this, with postgraduate education respondents having $63.0 \%$, and those with primary education having $20.0 \%$ (Table 3 ). Only $4.7 \%$ of the entire respondents did not know that avoiding unnecessary blood transfusion in Zika virus endemic areas could be infection prevention measure; while as many as $41.4 \%$ are not sure of the correct response. This finding can be considered impressive when compared with findings on the knowledge, about transmission of Zika virus through blood transfusion in some developed and developing countries. About half (51\%) of the respondents in a study on "Knowledge and Prevention Practices among U.S. 
Pregnant Immigrants from Zika Virus Outbreak Areas" knew that Zika virus can be transmitted through blood transfusion [32]. In a study conducted in some universities in Qatar, to assess the knowledge and perceptions about Zika virus, only $22.9 \%$ of the female respondents knew that Zika virus can be transmitted through blood transfusion [38]. Again, the finding that very few (17.1\%) respondents in a Zika virus study in Philippines knew that the infection can be transmitted through blood transfusion [33], is reasonably lower than our finding of $53.9 \%$ having the knowledge that Zika virus infection can be prevented by avoiding unnecessary blood transfusion in endemic areas.

Slightly more than half of the female caregivers that participated in this study (51.2\%) knew that avoiding eating too many oily meals does not prevent Zika virus infection. This is an indication that many people from this study location where myths such as eating of oily meals being a causative factor for febrile illnesses exist [27] [28], stilled had good knowledge about this. It is encouraging to note that most of the correct response came from women in the childbearing age group (Table 2). Educational level of the respondents also positively contributed to the overall knowledge score of the respondents. Nobody without formal education, or primary school level had the correct knowledge; while the highest knowledge score of $63.0 \%$ came from the postgraduate educational group (Table 3). Our finding could be considered better than findings in some developed countries such as Greece, if knowledge on transmission could be considered an indicator on prevention method knowledge; where $26.5 \%$ of respondents (pregnant women) strongly agreed/agreed that Zika virus infection can be transmitted through consumption of contaminated food [39]. Only 5.1\% of respondents in our study agreed that Zika virus infection can be prevented by avoiding eating too much oily meals. Again respondents in our study demonstrated better knowledge than medical students in Saudi Arabia, where only $24.9 \%$ of them knew that Zika virus infection cannot be transmitted through food [40]. No respondent outside the childbearing age knew that Zika virus does not have vaccine for prevention, and most of the correct response came from persons aged 20 to 30 years (Table 2). Overall the knowledge level was poor (37.5\%), and almost half of the respondents were not certain of which response to give (49.2\%). Higher educational qualification also appears to have enhanced the respondents' knowledge on Zika virus not having a vaccine. All the correct response came from persons who had at least secondary educational qualification (Table 3). It is important that care be taken in designing any Zika virus awareness programme for females, to incorporate simple communication methods and channels that will be easily understood by the less formally educated. Our finding about non-availability of Zika virus vaccine was reasonably better than finding in some other developing countries such as Philippines, where as few as $4.9 \%$ of pregnant women in a 2018 study knew that there is no vaccine for Zika virus prevention [35]. The very poor finding in Philippines could be indicative of inadequate Zika virus awareness creation activities in that study area. 


\section{Conclusion}

Knowledge of Zika virus prevention methods is very crucial among the general population, especially females of childbearing age since the neurological effects on unborn babies of infected pregnant women are of significant public health importance. Female caregivers that brought babies for immunization at this tertiary hospital in Southeast Nigeria had good knowledge on protection against mosquito bites, and avoiding unnecessary blood transfusion in endemic areas, as Zika virus infection prevention methods. They, however, recorded poor knowledge on safer sex-related prevention methods, and no availability of Zika virus vaccine. Respondents in the childbearing age group, and those with higher educational qualifications, generally exhibited higher knowledge level than the others. Sensitization, or awareness creation activities for persons in this study area, ought to be designed to address the observed gaps.

\section{Conflicts of Interest}

The authors declare no conflicts of interest with respect to research and publication of this original research paper.

\section{References}

[1] Akunne, M.O., Chukwueke, U.C. and Anosike, C. (2018) Assessment of Knowledge of Zika Virus Infection among Health Care Professionals in a Southeastern State of Nigeria. International Journal of Pharmacy and Pharmaceutical Sciences, 10, 56-60, https://doi.org/10.22159/ijpps.2018v10i2.22634

[2] Dick, G.W., Kitchen, S.F. and Haddow, A.J. (1952) Zika Virus (I). Isolations and Serological Specificity. Transactions of the Royal Society of Tropical Medicine and Hygiene, 46, 509-520. https://doi.org/10.1016/0035-9203(52)90042-4

[3] World Health Organization (2018) Zika Virus Key Facts. https://www.who.int/news-room/fact-sheets/detail/Zika-virus

[4] Diallo, D., Sall, A.A., Diagne, C.T., Faye, O., Faye, O., Ba, Y., Hanley, K.A., Buenemann, M., Weaver, S.C. and Diallo, M. (2014) Zika Virus Emergence in Mosquitoes in Southeastern Senegal, 2011. PLoS ONE, 9, e109442.

https://doi.org/10.1371/journal.pone.0109442

[5] Alera, M.T., Hermann, L., Tac-An, I.A., Klungthong, C., Rutvisuttinunt, W., Manasatienkij, W., et al. (2015) Zika Virus Infection, Philippines. Emerging Infectious Diseases, 21, 722-724. https://doi.org/10.3201/eid2104.141707

[6] Kwong, J.C., Druce, J.D. and Leder, K. (2013) Zika Virus Infection Acquired during Brief Travel to Indonesia. The American Journal of Tropical Medicine and Hygiene, 89, 516-517. https://doi.org/10.4269/ajtmh.13-0029

[7] Leung, G.H.Y., Baird, R.W., Druce, J. and Anstey N.M. (2015) Zika Virus Infection in Australia Following a Monkey Bite in Indonesia. The Southeast Asian Journal of Tropical Medicine and Public Health, 46, 460-464.

[8] Bogoch, I.I., Brady, O.J., Kraemer, M.U.G., German, M., Creatore, M.I., Kulkarni, M.A., et al. (2016) Anticipating the International Spread of Zika Virus from Brazil. The Lancet, 387, 335-336. https://doi.org/10.1016/S0140-6736(16)00080-5

[9] Shwe, D., Nathan, Y., Victor, C. and Kenneth, O. (2018) Epideiologic Review of Zika Virus Disease. Nigeria Journal of Medicine, 27, 180-187. 
https://doi.org/10.4103/1115-2613.278777

[10] Baden, L.R., Petersen, L.R., Jamieson, D.J., Powers, A.M. and Honein, M.A. (2016) Zika Virus. The New England Journal of Medicine, 374, 1552-1563. https://doi.org/10.1056/NEJMra1602113

[11] D’Ortenzio, E., Matheron, S., de Lamballerie, X., Hubert, B., Piorkowski, G., Maquart, M., Descamps, D., Damond, F., Yazdanpanah, Y. and Leparc-Goffart, I. (2016) Evidence of Sexual Transmission of Zika Virus. The New England Journal of Medicine, 374, 2195-2198. https://doi.org/10.1056/NEJMc1604449

[12] Hills, S.L., Russell, K., Hennessey, M., Williams, C., Oster, A.M., Fischer, M., et al. (2016) Transmission of Zika Virus through Sexual Contact with Travelers to Areas of Ongoing Transmission-Continental United States. Morbidity and Mortality Weekly Report, 65, 215-216. https://doi.org/10.15585/mmwr.mm6508e2

[13] Deckard, D.T., Chung, W.M., Brooks, J.T., Smith, J.C., Woldai, S., Hennessey, M., Kwit, N. and Mead, P. (2016) Male-to-Male Sexual Transmission of Zika Virus-Texas, January 2016. Morbidity and Mortality Weekly Report, 65, 372-374. https://doi.org/10.15585/mmwr.mm6514a3

[14] Musso, D., Roche, C., Robin, E., Nhan, T., Teissier, A. and Cao-Lormeau, V.M. (2015) Potential Sexual Transmission of Zika Virus. Emerging Infectious Diseases, 21, 359-361. https://doi.org/10.3201/eid2102.141363

[15] Stagg, D. and Hurst, H.M. (2016) Zika Virus and Pregnancy. Nursing for Women's Health, 20, 299-304. https://doi.org/10.1016/j.nwh.2016.03.001

[16] World Health Organization (2016) Situation Report: Zika Virus, Microcephaly, Guillain-Barré Syndrome. World Health Organization. https://apps.who.int/iris/handle/10665/250633

[17] Centers for Disease Control and Prevention (2018) Zika and Blood Transfusion. https://www.cdc.gov/Zika/transmission/blood-transfusion.html

[18] Okafor, I.I., Ezugwu, F.O. and Ekwochi, U. (2016) Zika Virus: The Emerging Global Health Challenge. Diversity and Equality in Health and Care, 13, 394-401. https://doi.org/10.21767/2049-5471.100083

[19] MacNamara, F.N. (1954) Zika Virus: A Report on Three Cases of Human Infection during an Epidemic of Jaundice in Nigeria. Transactions of the Royal Society of Tropical Medicine and Hygiene, 48, 139-145. https://doi.org/10.1016/0035-9203(54)90006-1

[20] World Population Review. https://www.worldometers.info/world-population/nigeria-population/

[21] Wikipedia. https://en.wikipedia.org/wiki/Enugu

[22] Araoye, M.O. (2003) Research Methodology with Statistics for Health and Social Sciences. Nathadex Publishers, Ilorin.

[23] World Health Organization (2016) Zika Virus Research Agenda. World Health Organization, Geneva.

[24] Savage, H.M., Ezike, V.I., Nwankwo, A.C., Spiegel, R. and Miller, B.R. (1992) First Record of Breeding Populations of Aedes albopictus in Continental Africa: Implications for Arboviral Transmission. Journal of the American Mosquito Control Association, 8, 101-103.

[25] Fagbemi, A., Tomori, O. and Fabiyi, A. (1997) A Virological and Clinical Observations during an Outbreak of Dengue and Dengue-Like Illnesses at Abeokuta. Nigerian Journal of Medicine, 7, 380-383.

[26] World Health Organization. http://www.who.int/csr/disease/Zika/en/ 
[27] Ndibuagu, E.O., Arinze-Onyia, S.U. and Igweagu, P.C. (2016) Knowledge of Causes and Complications of Malaria, among Residents of a Rural Community in Enugu State, Southeast Nigeria. International Research Journal of Medicine and Medical Sciences, 4, 1-5.

[28] Ahorlu, C.K., Koram, K.W., Ahorlu, C., de-Savigny, D. and Weiss, M.G. (2005) Community Concepts of Malaria-Related Illnesses with and without Convulsions in Southern Ghana. Malaria Journal, 4, Article NO. 47.

https://doi.org/10.1186/1475-2875-4-47

[29] Ndibuagu, E.O., Okafor, I.I., Arinze-Onyia, S.U. (2017) Age Related Pattern of Awareness and Basic Knowledge on Zika Virus Disease among Women Visiting Children Immunization Unit in Enugu State University Teaching Hospital, Southeast Nigeria. International Journal of Tropical Disease and Health, 35, 1-12.

[30] Ndibuagu, E.O. (2018) Formal Education Related Pattern of Awareness and Basic knowledge on Zika Virus Disease, among women Visiting Children Immunization Unit in a Tertiary Hospital, Southeast Nigeria. Health, 10, 1576-1596. https://doi.org/10.4236/health.2018.1011119

[31] Weldon, C.T., Riley-Powell, A.R., Aguerre, I.M., Celis Nacimento, R.A., Morrison, A.C., Oberhelman, R.A. and Paz-Soldan, V.A. (2018) "Zika Is Everywhere": A Qualitative Exploration of Knowledge, Attitudes and Practices towards Zika Virus among Women of Reproductive Age in Iquitos, Peru. PLOS Neglected Tropical Diseases, 12, e0006708. https://doi.org/10.1371/journal.pntd.0006708

[32] Berenson, A.B., Trinh, H.N., Hirth, J.M., Guo, F., Fuchs, E.L. and Weaver, S.C. (2017) Knowledge and Prevention Practices among U.S. Pregnant Immigrants from Zika Virus Outbreak Areas. American Society of Tropical Medicine and Hygiene, 97, 155-162. https://doi.org/10.4269/ajtmh.17-0062

[33] Gregorio, E.R., Medina, J.R.C., Lomboy, M.F.T.C., Talaga, A.D.P., Hernandez, P.M.R., Kodama, M., et al. (2019) Knowledge, Attitudes, and Practices of Public Secondary School Teachers on Zika Virus Disease: A Basis for the Development of Evidence-Based Zika Educational Materials for Schools in the Philippines. PLoS ONE, 14, e0214515. https://doi.org/10.1371/journal.pone.0214515

[34] Arguelles-Nava, V.G., Alvarez-Banuelos, M.T., Cordoba-Suarez, D., Sampieri, C.L. Ortiz-Leon, M.C., Riande-Juarez, G. and Montero, H. (2018) Knowledge, Attitudes, and Practices about Zika among a University Community Located in an Endemic Zone in Mexico. International Journal of Environmental Research and Public Health, 15, Article ID: 2548. https://doi.org/10.3390/ijerph15112548

[35] Ricamonte, B.T.P., Jover, C.C.G., Oducado, R.M.F., Ngitngit, E.J.M., Hiponia, A.Y.S. and Macables, G.H.P. (2018) Knowledge and Attitude toward Zika Virus Disease among Pregnant Women in Iloilo City, Philippines. Public Health Research, 8, 115-120.

[36] Michael, G.C., Aliyu, I., Grema, B.A. and Ashimi, A.O. (2017) Knowledge of Zika Virus Disease among Reproductive-Age Women Attending a General Outpatient Clinic in Northern Nigeria. South African Family Practice, 59, 148-153. https://doi.org/10.1080/20786190.2017.1313484

[37] Samuel, G., Di Bartolo-Cordovano, R., Taj, I., Merriam, A., Lopez, J.M., Torres, C., et al. (2018) A Survey of the Knowledge, Attitudes and Practices on Zika Virus in New York City. BMC Public Health, 18, Article No. 98. https://doi.org/10.1186/s12889-017-4991-3

[38] Cheema, S., Maisonneuve, P., Weber, I., Fernandez-Luque, L., Abraham, A., Alrouh, H., et al. (2017) Knowledge and Perceptions about Zika Virus in a Middle East Country. BMC Infectious Diseases, 17, Article No. 524. 
https://doi.org/10.1186/s12879-017-2603-6

[39] Mouchtouri, V.A., Papagiannis, D., Katsioulis, A., Rachiotis, G., Dafopoulos, K. and Hadjichristodoulous, C. (2017) Knowledge, Attitudes, and Practices about the Prevention of Mosquito Bites and Zika Virus Disease in Pregnant Women in Greece. International Journal of Environmental Research and Public Health, 14, Article No. 367. https://doi.org/10.3390/ijerph14040367

[40] Ibrahim, N.K., Moshref, R.H., Moshref, L.H., Walid, J.B. and Alsati, H.S. (2017) Knowledge and Attitudes towards Zika Virus among Medical Students in King Abdulaziz University, Jeddah, Saudi Arabia. Journal of Infection and Public Health, 11, 18-23. https://doi.org/10.1016/j.jiph.2017.02.015 